\begin{tabular}{|l|l|l||}
\hline \multicolumn{2}{|c|}{ PublisherInfo } \\
\hline \hline PublisherName & $:$ & BioMed Central \\
\hline \hline PublisherLocation & $:$ & London \\
\hline \hline PublisherImprintName & $:$ & BioMed Central \\
\hline \hline
\end{tabular}

\title{
Killer genome
}

\begin{tabular}{|l|l|l||}
\hline \multicolumn{2}{|c|}{ ArticleInfo } \\
\hline \hline ArticleID & $:$ & 3965 \\
\hline \hline ArticleDOI & $:$ & $10.1186 /$ gb-spotlight-20010125-02 \\
\hline \hline ArticleCitationID & $:$ & spotlight-20010125-02 \\
\hline \hline ArticleSequenceNumber & $:$ & 36 \\
\hline \hline ArticleCategory & $:$ & Research news \\
\hline \hline ArticleFirstPage & $:$ & 1 \\
\hline \hline ArticleLastPage & $:$ & 2 \\
\hline \hline & & RegistrationDate : 2001-01-25 \\
ArticleHistory & $:$ & OnlineDate $\quad$ 2001-01-25 \\
\hline \hline ArticleCopyright & $:$ & BioMed Central Ltd2001 \\
\hline \hline ArticleGrants & $:$ & \\
\hline \hline ArticleContext & $:$ & 130592211 \\
\hline \hline
\end{tabular}




\section{Jonathan B Weitzman}

Email: jonathanweitzman@hotmail.com

O157:H7 is the unassuming name of a deadly strain of Escherichia coli that has been killing thousands of people every year, ever since the first outbreak was caused by contaminated hamburgers in 1982. In the January 25 Nature Perna et al. describe the sequencing of the entire genome of this killer bug in search of clues to its pathogenesis (Nature 2001, 409:529-533). Comparison with the genome of non-pathogenic laboratory E. coli strain K-12 revealed 1,387 new genes, which are organized into distinct strain-specific clusters sprinkled throughout the 4.1 megabases of sequence. Any of these differences may be related to disease-related traits of O157:H7. These results should aid in the development of sensitive diagnostic tools and in pinpointing the killer genes.

\section{References}

1. Escherichia coli O157:H7, [http://vm.cfsan.fda.gov/ mow/chap15.html]

2. Nature, [http://www.nature.com/]

3. The complete genome sequence of Escherichia coli K-12. 